\title{
GMR
}

\section{Genetic diversity among air yam (Dioscorea bulbifera) varieties based on single sequence repeat markers}

\author{
D.M. Silva ${ }^{1}$, M.V.B.M. Siqueira ${ }^{2}$, N.F. Carrasco ${ }^{1}$, C.C. Mantello ${ }^{3}$, \\ W.F. Nascimento ${ }^{4}$ and E.A. Veasey ${ }^{1}$ \\ 'Departamento de Genética, Escola Superior de Agricultura “Luiz de Queiroz", \\ Universidade de São Paulo, Piracicaba, SP, Brasil \\ ${ }^{2}$ Central de Laboratórios de Pesquisa, Ciência e Tecnologia Ambiental, \\ Universidade do Sagrado Coração, Bauru, SP, Brasil \\ ${ }^{3}$ Centro de Biologia Molecular e Engenharia Genética, \\ Universidade Estadual de Campinas, Campinas, SP, Brasil \\ ${ }^{4}$ Centro de Ciências Agrárias e Ambientais, Universidade Federal do Maranhão, \\ Chapadinha, MA, Brasil
}

Corresponding author: E.A. Veasey

E-mail: eaveasey@usp.br

Genet. Mol. Res. 15 (2): gmr.15027929

Received October 27, 2015

Accepted December 10, 2015

Published May 23, 2016

DOI http://dx.doi.org/10.4238/gmr.15027929

\begin{abstract}
Dioscorea is the largest genus in the Dioscoreaceae family, and includes a number of economically important species including the air yam, D. bulbifera $\mathrm{L}$. This study aimed to develop new single sequence repeat primers and characterize the genetic diversity of local varieties that originated in several municipalities of Brazil. We developed an enriched genomic library for D. bulbifera resulting in seven primers, six of which were polymorphic, and added four polymorphic loci developed for other Dioscorea species. This resulted in 10 polymorphic primers to evaluate 42 air yam accessions. Thirtythree alleles (bands) were found, with an average of 3.3 alleles per locus. The discrimination power ranged from 0.113 to 0.834 , with an
\end{abstract}


average of 0.595 . Both principal coordinate and cluster analyses (using the Jaccard Index) failed to clearly separate the accessions according to their origins. However, the 13 accessions from Conceição dos Ouros, Minas Gerais State were clustered above zero on the principal coordinate 2 axis, and were also clustered into one subgroup in the cluster analysis. Accessions from Ubatuba, São Paulo State were clustered below zero on the same principal coordinate 2 axis, except for one accession, although they were scattered in several subgroups in the cluster analysis. Therefore, we found little spatial structure in the accessions, although those from Conceição dos Ouros and Ubatuba exhibited some spatial structure, and that there is a considerable level of genetic diversity in $D$. bulbifera maintained by traditional farmers in Brazil.

Key words: Dioscorea bulbifera; Genetic structure; Germplasm; Microsatellite; Microsatellite development; Traditional agriculture

\section{INTRODUCTION}

Dioscorea bulbifera L. belongs to the Dioscoreaceae family, section Opsophyton, and is one of the most important cultivated species within the genus (Lebot, 2009), although it is also considered an invasive weed in North America (Croxton et al., 2011). It has high therapeutic potential, and is considered a potential species to replace D. deltoidea Wall. ex Griseb., as the main source of diosgenin. Although only traces of diosgenin have been detected in D. bulbifera, it is widely used in traditional medicine (Correa, 1978; Narula et al., 2003; Sougata et al., 2012).

D. bulbifera is the only species of the genus that originated in both Asia and Africa, and is still found in the wild. Asian varieties have less angular, more spherical, and less toxic tubers than African varieties (Lebot, 2009). According to Martin and Ortiz (1963), D. bulbifera with $\mathrm{N}=9$ has been found in Africa and the Americas, while individuals with $\mathrm{N}=10$ have been found in Asia. Using flow cytometry, Obidiegwu et al. (2009a) found diploid (2X), triploid (3X), tetraploid (4X), hexaploid (6X), and octoploid (8X) ploidy levels in Dioscorea species, while the three D. bulbifera accessions studied were hexaploids (6X). D. bulbifera is believed to have been introduced into Brazil by Dutch settlers (Correa, 1978). It is known globally as the air yam, aerial yam, or air potato, and in Brazil it has several vernacular names that have all been inspired by the shape of its bulbils, such as cará do ar (air yam), cará moela (gizzard yam), cara fígado (liver yam), cará paquera (flert yam), cará de árvore (tree yam), cará de cipó (liana yam), and cará preto (black yam) (Bressan et al., 2005; Veasey et al., 2010).

Microsatellites, or simple sequence repeats (SSRs), are widely used molecular markers because of their codominant and highly polymorphic nature, their random distribution throughout the genome, and their high reproducibility (Sosinski et al., 2000). Several SSR primers have been developed and used to assess the genetic diversity and structure of yam species, such as cultivated D. alata (Tostain et al., 2006; Sartie et al., 2012; Siqueira et al., 2011, 2014), D. trifida (Hochu et al., 2006; Nascimento et al., 2013), and D. cayenensis/D. rotundata (Tostain et al., 2007; Obidiegwu et al., 2009b; Sartie et al., 2012; Scarcelli et al., 2005, 2013; Mengesha et al., 2013; Silva et al., 2014). Recently, 14 SSR loci were developed for $D$. bulbifera accessions from China using the dual-suppression polymerase chain reaction (PCR) technique (Yan et al., 2014). 
The first study of $D$. bulbifera using molecular markers was by restriction fragment length polymorphism (RFLP) of cpDNA (Terauchi et al., 1991), and compared 15 accessions from Africa and Asia and their differentiation. The genetic diversity of D. bulbifera accessions from Africa, Asia, and Polynesia was subsequently assessed using random amplified polymorphic DNA (RAPD) (Ramser et al., 1996). This marker was also used to assess in vitro D. bulbifera regenerants by Dixit et al. (2003) and Narula et al. (2003). Amplified fragment length polymorphism (AFLP) markers were used to investigate the genetic diversity of 48 yam accessions from Ethiopia, including five D. bulbifera accessions (Tamiru et al., 2007). This study concluded that $D$. bulbifera was closer to $D$. alata than to $D$. cayenensis, $D$. rotundata, and other Ethiopian accessions (Tamiru et al., 2007). This marker was also used by Malapa et al. (2005) to investigate relationships between D. bulbifera and other Dioscorea spp. Croxton et al. (2011) compared accessions from Florida, USA with those from Africa and China using cpDNA sequences, and showed that the Florida accessions were more closely related to those introduced from China than to those from Africa. D. bulbifera was also evaluated using cpDNA sequences by Scarcelli et al. (2011), although the emphasis of this study was on African accessions of $D$. rotundata, D. abyssinica, and D. prehensilis. In Brazil, isozyme markers were used to study genetic diversity among local varieties of D. bulbifera from the Vale do Ribeira, São Paulo State (Veasey et al., 2014). The only studies that have used SSR markers in air yams are Yan et al. (2014), as mentioned above, and Croxton et al. (2011), who only used two SSR primers in addition to the cpDNA sequences.

With the objective of obtaining further information on the genetics of D. bulbifera, the present study aimed to develop new SSR primer pairs and assess the genetic diversity and structure of accessions from different states and municipalities of Brazil.

\section{MATERIAL AND METHODS}

Forty-two D. bulbifera accessions were evaluated in this study, with 25 collected in the state of São Paulo, 13 collected in the state of Minas Gerais, and one each collected in the states of Mato Grosso, Goiás, Pernambuco, and Piauí (Table 1; Figure 1). Some of the accessions were obtained in local markets, but most of them represent local varieties obtained from local farmers.

\section{Enriched genomic library development and SSR genetic characterization}

Genomic DNA was extracted from previously lyophilized leaves using a DNeasy ${ }^{\circledR}$ Plant Mini Kit (Qiagen Ltd., Crawley, West Sussex, UK), with the addition of polyvinylpyrrolidone in one of the stages of the process to eliminate phenolic compounds and polysaccharides. DNA was quantified on 1\% agarose gels, stained with Blue Green (LGC Biotecnologia, São Paulo, SP, Brazil), and photodocumented.

An enriched genomic library was constructed using the methodology developed by Billotte et al. (1999). After sequencing, the sequences obtained were analyzed and edited in the $\mathrm{SeqMan}^{\mathrm{TM}}$ II program (DNASTAR Inc.). This program forms contigs from two or more reads, and directly deletes data of poor quality from several automatic sequencers. Microsat software (CIRAD, France) was used to exclude clone sequences and adapters. After this procedure, we identified regions containing microsatellites using the SSRIT program (Temnykh et al., 2001), which is available at http://www.gramene.org/db/searches/ssrtool. Primers were then designed using the PrimerSelect program (DNASTAR Inc.) under the following conditions: fragment 
size of 100-300 bp, GC content of between 40 and $60 \%$, annealing temperature between $45^{\circ}$ and $60^{\circ} \mathrm{C}$, primer size between 18 and $22 \mathrm{bp}$, and an absence of hairpins or dimers.

Table 1. Characteristics of Dioscorea bulbifera accessions collected in Brazil.

\begin{tabular}{|c|c|c|c|c|}
\hline No. & Accession & Municipality & Community & Folk name \\
\hline 1 & DGC-25 & Iguape-SP & Momuna & Cará moela \\
\hline 2 & DGC-30 & Iguape-SP & Peropava & Cará moela \\
\hline 3 & DGC-317 & Iguape-SP & Peropava & Cará moela \\
\hline 4 & DGC-54 & Cananéia-SP & Agrossolar & Cará paquera \\
\hline 5 & DGC-58 & Cananéia-SP & Aroeira & Cará moela \\
\hline 6 & DGC-63 & Cananéia-SP & Porto Cubatão & Cará moela \\
\hline 7 & DGC-65 & Cananéia-SP & Prainha & Cará moela \\
\hline 8 & DGC-66 & Cananéia-SP & Prainha & Cará moela \\
\hline 9 & DGC-102 & Iporanga-SP & Betarí & Cará paquera \\
\hline 10 & DGC-118* & Iporanga-SP & Amapá & - \\
\hline 11 & DGC-122 & Anhembi-SP & - & - \\
\hline 12 & DGC-35 & Campinas-SP & (IAC) & Áspero normal \\
\hline 13 & DGC-218 & Ubatuba-SP & Fazenda da Caixa & Cará moela \\
\hline 14 & DGC-219 & Ubatuba-SP & Sertão Ubatumirim & Cará moela \\
\hline 15 & DGC-220 & Ubatuba-SP & Quilombo Camburi & Cará moela \\
\hline 16 & DGC-221 & Ubatuba-SP & Sertão do Ingá & Cará moela \\
\hline 17 & DGC-222 & Ubatuba-SP & Sertão das Cutias & Cará moela \\
\hline 18 & DGC-223 & Ubatuba-SP & Sertão do Ingá & Cará moela \\
\hline 19 & DGC-224 & Ubatuba-SP & Sertão do Ingá & Cará moela \\
\hline 20 & DGC-225 & Ubatuba-SP & Sertão do Ingá & Cará moela \\
\hline 21 & DGC-227 & Ubatuba-SP & Rio Escuro & Cará moela \\
\hline 22 & DGC-230 & Ubatuba-SP & Sertão do Quina & Cará moela \\
\hline 23 & DGC-244 & São José dos Campos-SP & - & Cará moela \\
\hline 24 & DGC-383 & São José dos Campos-SP & - & - \\
\hline 25 & DGC-387 & São Luiz do Paraitinga-SP & - & - \\
\hline 26 & DGC-274 & Conceição dos Ouros-MG & Cesários & Cará de árvore \\
\hline 27 & DGC-275 & Conceição dos Ouros-MG & Sertãozinho & Cará de cipó \\
\hline 28 & DGC-276 & Conceição dos Ouros-MG & Sertãozinho & Cará de árvore \\
\hline 29 & DGC-277 & Conceição dos Ouros-MG & Pereiras & Cará de árvore \\
\hline 30 & DGC-280 & Conceição dos Ouros-MG & Três Cruzes & Cará figado \\
\hline 31 & DGC-373 & Conceição dos Ouros-MG & Barbosas & Cará moela \\
\hline 32 & DGC-375 & Conceição dos Ouros-MG & Bernardino & Cará moela \\
\hline 33 & DGC-376 & Conceição dos Ouros-MG & Maias & Cará moela \\
\hline 34 & DGC-379 & Conceição dos Ouros-MG & Barro Branco & Cará moela \\
\hline 35 & DGC-380 & Conceição dos Ouros-MG & Campo do Meio & Cará de árvore \\
\hline 36 & DGC-381 & Conceição dos Ouros-MG & Campo do Meio & Cará cipó \\
\hline 37 & DGC-384 & Conceição dos Ouros-MG & Ribeirão Pequeno & Cará \\
\hline 38 & DGC-385 & Conceição dos Ouros-MG & Ribeirão Pequeno & Cará de árvore \\
\hline 39 & DGC-245* & Pirenópolis-GO & - & Cará moela \\
\hline 40 & DGC-134 & Tangará da Serra-MT & - & - \\
\hline 41 & DGC-169 & Regeneração-PI & Chapada Gugel & Inhame figo \\
\hline 42 & DGC-273 & Camocim de São Félix-PE & Santa Lusia & Cará moela \\
\hline
\end{tabular}

Asterisks indicate accessions obtained in local markets.

PCRs for the primers developed in this study were conducted in a $10-\mu \mathrm{L}$ volume containing $10 \mathrm{ng}$ genomic DNA template, 2.5 U Taq DNA polymerase (LGC Biotecnologia), $10 \mathrm{X}$ amplification buffer $\left(\mathrm{Mg}^{2+}\right.$ free), 5\% bovine serum albumin, $3.6 \mathrm{mM} \mathrm{MgCl}, 0.4 \mu \mathrm{M}$ of each primer, and $2.5 \mathrm{mM}$ of each dNTP using an automated thermal cycler (Bioer Technology, Hangzhou, China). For the primers developed by Tostain et al. (2006), we conducted a PCR in a $10-\mu \mathrm{L}$ volume that contained $10 \mathrm{ng}$ genomic DNA template, $0.5 \mathrm{U}$ Taq DNA polymerase (LGC Biotecnologia), 10X amplification buffer $\left(\mathrm{Mg}^{2+}\right.$ free), $2.0 \mathrm{mM} \mathrm{MgCl}{ }_{2}, 0.6 \mu \mathrm{M}$ of each primer, and $2.0 \mathrm{mM}$ of each dNTP. 


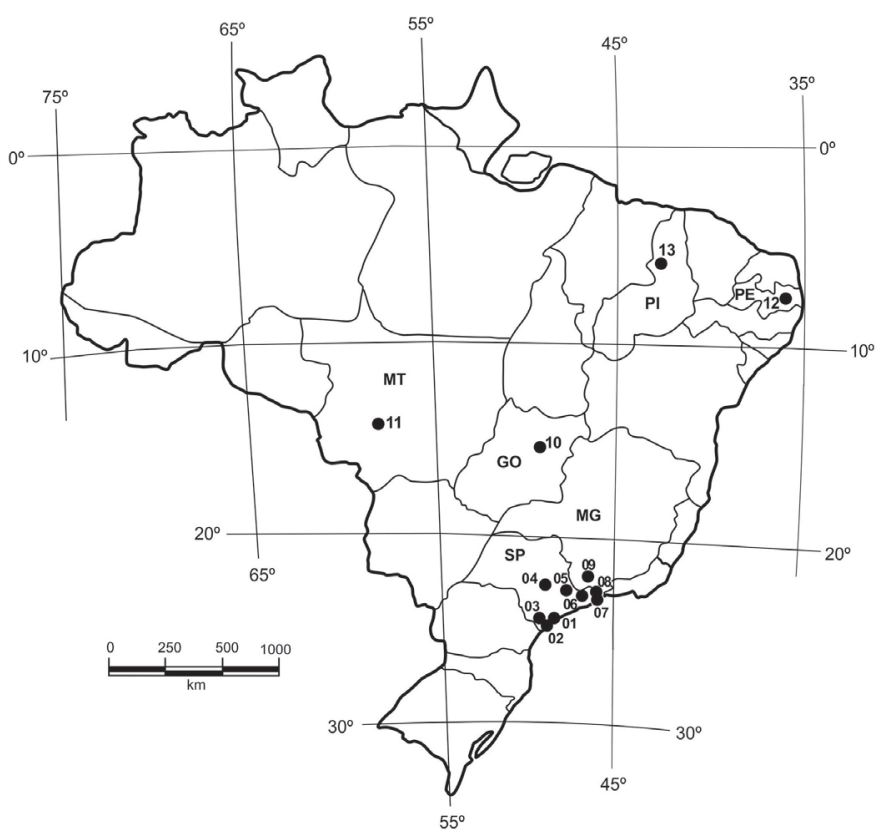

Figure 1. Dioscorea bulbifera accession sampling locations in Brazil. 1, Iguape-SP; 2, Cananéia-SP; 3, IporangaSP; 4, Anhembi-SP; 5, Campinas-SP; 6, São José dos Campos-SP; 7, Ubatuba-SP; 8, São Luiz do Paraitinga-SP; 9, Conceição dos Ouros-MG; 10, Pirenópolis-GO; 11, Tangará da Serra-MT; 12, Camocim de São Félix-PE; 13, Regeneração-PI.

The PCRs were conducted using a MyCycler ${ }^{\mathrm{TM}}$ Thermal Cycler (Bio-Rad Laboratórios Brasil Ltd., São Paulo, SP, Brazil) with the following steps: an initial denaturing step for 5 min at $94^{\circ} \mathrm{C}$, followed by 10 preamplification cycles $\left(30 \mathrm{~s}\right.$ at $95^{\circ} \mathrm{C}, 30 \mathrm{~s}$ at the initial annealing temperature of $60^{\circ} \mathrm{C}$, decreasing by $1^{\circ} \mathrm{C}$ at each cycle, and $50 \mathrm{~s}$ at $72^{\circ} \mathrm{C}$ ), followed by 30 cycles of denaturing $\left(30 \mathrm{~s}\right.$ at $95^{\circ} \mathrm{C}, 30 \mathrm{~s}$ at $50^{\circ} \mathrm{C}$, and $50 \mathrm{~s}$ at $\left.72^{\circ} \mathrm{C}\right)$, and a final extension step for $5 \mathrm{~min}$ at $72^{\circ} \mathrm{C}$. The amplified products were separated on denaturing $7 \%$ polyacrylamide gels (C.B.S. Scientific, USA), and the products were visualized by silver staining according to the methods of Creste et al. (2001).

\section{Statistical analysis}

Because D. bulbifera is a polyploid species, microsatellite bands were assessed as the presence/absence of bands as dominant markers. The number of bands (alleles) per locus and the percentage of polymorphism were obtained for all analyzed accessions. To compare the efficiency of the markers in the identification of genotypes, parameter D (Tessier et al., 1999) was estimated, which confers the power of discrimination of each primer. This parameter was calculated according to the formula:

$$
\mathrm{D}_{\mathrm{j}}=1-\mathrm{C}_{\mathrm{j}}=1-\sum_{\mathrm{i}=1}^{1} \mathrm{pi} \frac{\left(\mathrm{N}_{\mathrm{pi}}-1\right)}{\mathrm{N}-1}
$$


where $\mathrm{D}$ is the probability that two randomly selected individuals have different band patterns, $\mathrm{C}$ is the probability that two randomly selected individuals have a similar band pattern, and $\mathrm{N}$ is the number of individuals analyzed.

Using the Jaccard similarity coefficient, cluster (unweighted pair group method with arithmetic mean) and principal coordinate analyses were conducted using PAST software (Hammer et al., 2001). The accuracy of the groupings was estimated from simulations with resampling, using 10,000 bootstraps. We also conducted a Bayesian analysis using the Structure program (Pritchard et al., 2000), which does not rely on prior information on possible groups based on the origin of the accessions. This analysis was run using the admixture model with correlated allele frequencies and repeated eight times for each $\mathrm{K}$ (number of assumed clusters), with a burn-in of 250,000 interactions that was followed by 500,000 Markov Chain Monte Carlo interactions. The most probable number of clusters was chosen using the $\Delta \mathrm{K}$ method (Evanno et al., 2005).

\section{RESULTS}

The genomic library was obtained and sequenced from 86 colonies (clones) containing the insert. Twenty-one colonies had microsatellite sequences, representing an enrichment of $24.4 \%$ of the library according to the protocol described by Billotte et al. (1999), who consider enrichment above $20 \%$ as high. Most of the repeat motifs (six of the seven primer pairs selected) were classified as dinucleotides, and all of them were classified as perfect. In total, we found 26 regions containing microsatellites. Among the 26 microsatellites obtained, seven SSR markers were selected (Table 2). Designing the remaining primer sequences was not possible because of their low quality. All of the SSR markers had synthesized amplicons, and only one (Db7) exhibited a monomorphic pattern.

Table 2. Characteristics of microsatellite primers developed for Dioscorea bulbifera.

\begin{tabular}{|c|c|c|c|c|c|}
\hline Name & Forward and reverse sequences & GenBank No. & $\mathrm{Ta}\left({ }^{\circ} \mathrm{C}\right)$ & Size $(\mathrm{pb})$ & Motif \\
\hline Db2 & $\begin{array}{l}\text { F: CACGACCTCCTGGAAGACAACT } \\
\text { R: ATATAGCACGGGAGGCACAAAC }\end{array}$ & KC110758 & 53 & 214 & $(\mathrm{GAC})_{4}$ \\
\hline Db3 & $\begin{array}{l}\text { F: TTTTACCCAGGATTTAGAAGAA } \\
\text { R: GGACTGGAGCCACAAGATT }\end{array}$ & KC110759 & 50 & 279 & $(\mathrm{CA})_{8}$ \\
\hline $\mathrm{Db} 4$ & $\begin{array}{l}\text { F: TCTCGCTGTTCTCGTGTTCTTC } \\
\text { R: GTCCGATTTGATGGTGCTTCTC }\end{array}$ & KC110760 & 55 & 194 & $(\mathrm{GA})_{17}$ \\
\hline Db5 & $\begin{array}{l}\text { F: TGTCTATTATATTGCTCTTTCT } \\
\text { R: CGTTTCTAATTTCTGGGTAT }\end{array}$ & KC110761 & 50 & 284 & $(\mathrm{GT})_{4}$ \\
\hline Db6 & $\begin{array}{l}\text { F: AAGCCGGTATCATTCAACAAAA } \\
\text { R: CCCTCGCCAACATCAAGTAA }\end{array}$ & KC110762 & 53 & 170 & $(\mathrm{AC})_{8}$ \\
\hline$\overline{\mathrm{Db} 7}$ & $\begin{array}{l}\text { F: CCGCAAGGCTCAAAAAGTTAGG } \\
\text { R: TCGTGGATGAAGATGGGTGGAC }\end{array}$ & KC110763 & 53 & 104 & $(\mathrm{GA})_{4}$ \\
\hline $\mathrm{Db} 8$ & $\begin{array}{l}\text { F: TCCCAAGAAATCCAGAATA } \\
\text { R: ATGCATGCCAAAACAAATA }\end{array}$ & KC110764 & 50 & 139 & $(\mathrm{TG})_{8}$ \\
\hline
\end{tabular}

$\mathrm{Ta}=$ annealing temperature

Thirty-three alleles (bands) were found for the 10 polymorphic loci analyzed, including the six primers developed in this study and four other loci obtained from the literature (Tostain et al., 2006), ranging from two to four alleles per locus, with an average of 3.3 alleles per locus and $100 \%$ polymorphism. The discrimination power (D) parameter ranged from 0.113 to 0.834 , with an average of 0.595 .

Neither principal coordinate nor cluster analysis could separate the accessions 
according to their origins (Figures 2 and 3). In addition, Bayesian analysis did not detect any groups (data not shown), confirming that the $D$. bulbifera accessions did not exhibit any spatial structure. However, 13 accessions from Conceição dos Ouros, Minas Gerais were clustered above zero on the principal coordinate 2 axis, which explained $12.1 \%$ of the total variation (Figure 3), and all of the accessions from Ubatuba, São Paulo (except for one accession, number 17) were clustered below zero on principal coordinate 2 axis, indicating a slight separation between these two locations. Other accessions from São Paulo and the other states were scatted without any clear pattern.

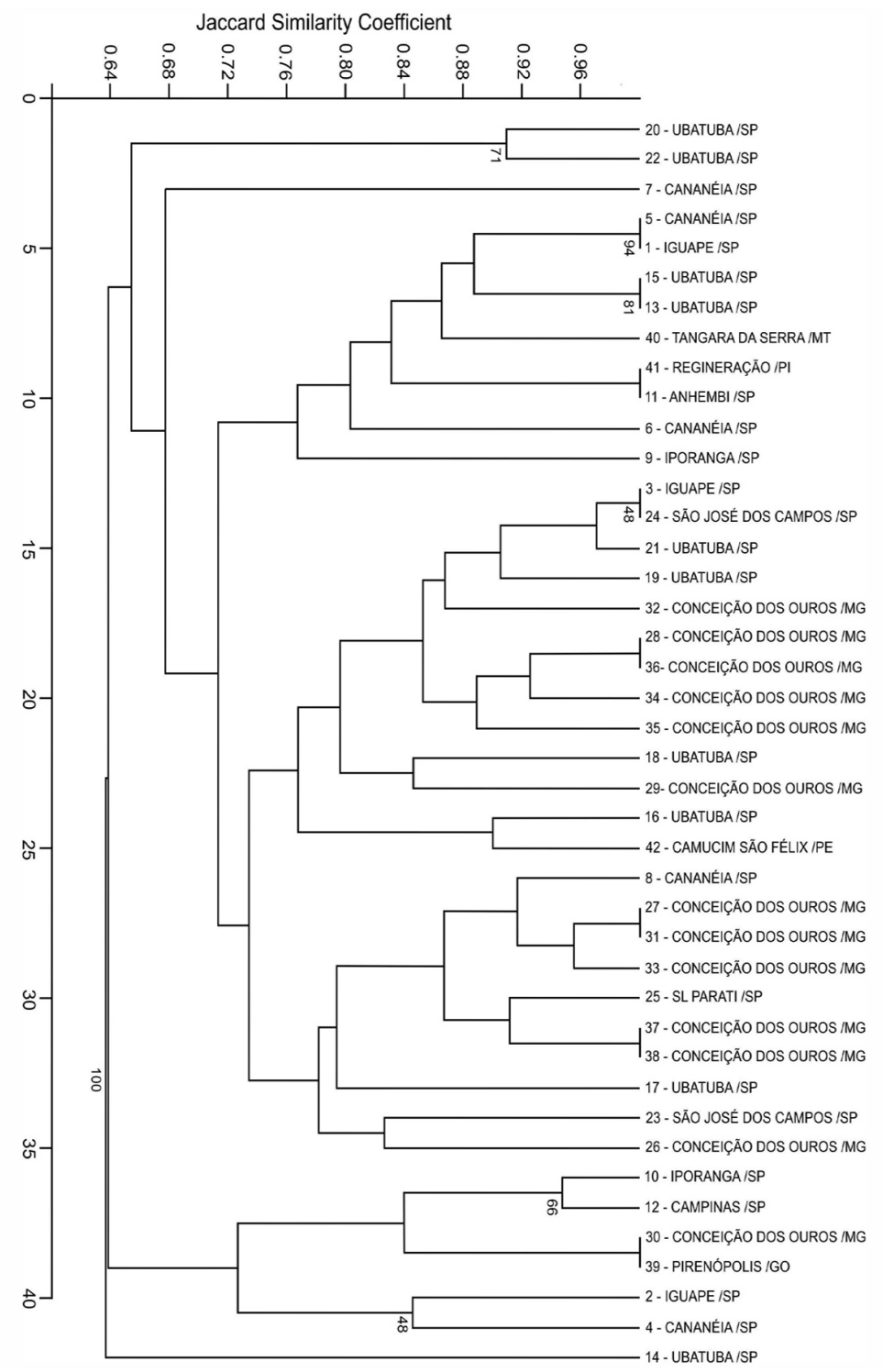

Figure 2. Cluster analysis of 42 Dioscorea bulbifera accessions from Brazil based on 10 simple sequence repeat loci. 


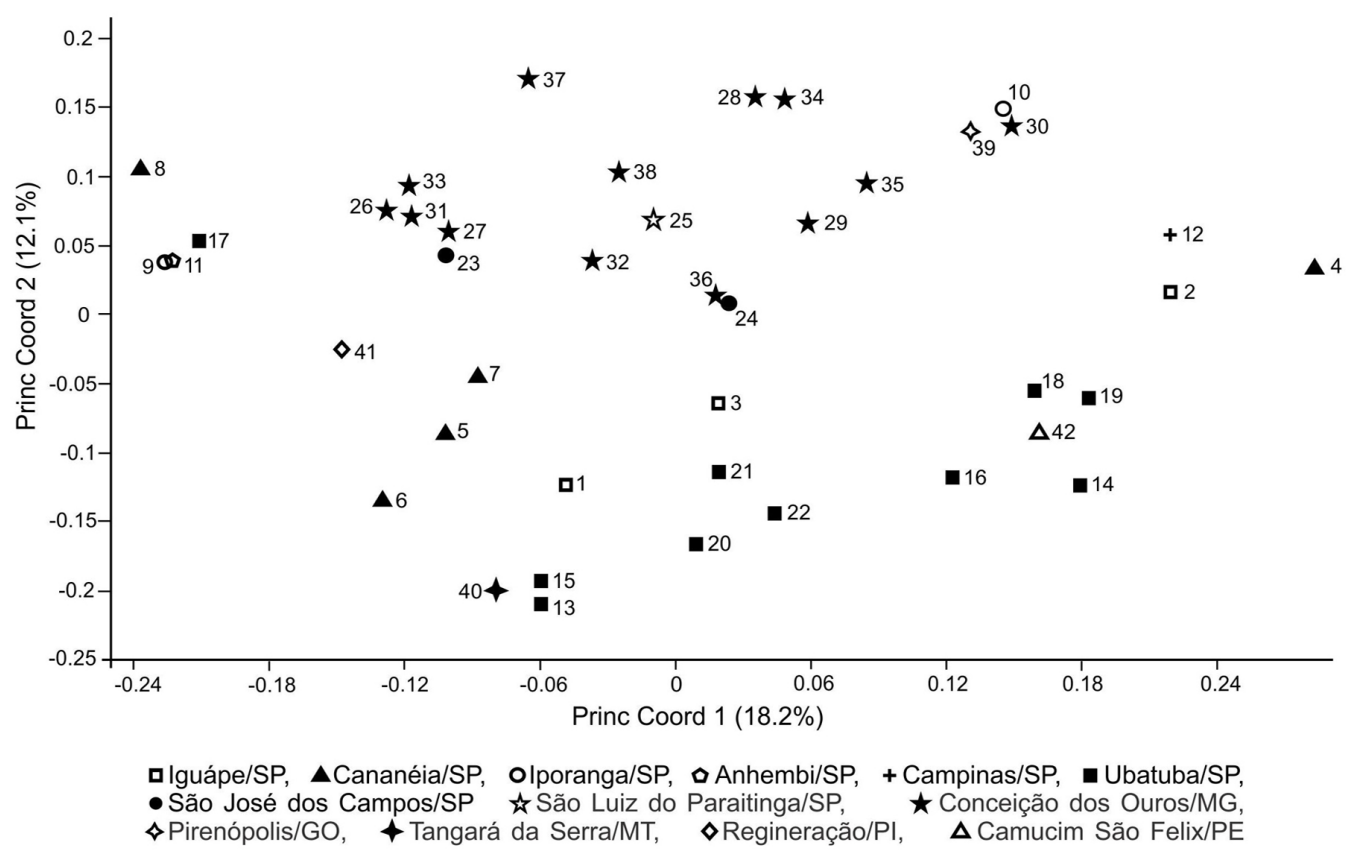

Figure 3. Principal coordinate analysis corresponding to $30.3 \%$ of the total variation in 42 Dioscorea bulbifera accessions from Brazil based on 10 simple sequence repeat loci.

The cluster analysis classified the accessions into two groups, with one group containing one accession from Ubatuba (number 14) and the other group the remainder of the accessions; therefore, no clear pattern was found in terms of accession origin in the two groups (Figure 2). Although not supported by the bootstrap analysis, three subgroups were identified in the group with most of the accessions, and one of these contained all of the Minas Gerais accessions. However, the 25 accessions from São Paulo were scattered into both groups and subgroups, both in the cluster analysis and in the principal coordinate analysis. Even accessions from the same municipality, such as Ubatuba or Iguape, were scattered into different groups and subgroups. Eight duplicates were found among the accessions; three of them included two accessions each from Conceição dos Ouros, Minas Gerais and a fourth with one accession from Conceição dos Ouros, Minas Gerais and one from Pirenópolis, Goiás. The other duplicates included accessions from different municipalities of São Paulo, and one included an accession each from Anhembi, São Paulo and Regeneração, Piauí. These two accessions had very distant origins and were clustered together.

\section{DISCUSSION}

The most frequent class of microsatellite found in this study was dinucleotide, corresponding to six of the seven primer pairs selected. The same dinucleotide predominance has been found for D. cayenensis (Silva et al., 2014) and D. alata (Tostain et al., 2006; Siqueira et al., 2011). Microsatellite loci of the perfect dinucleotide type are ideal for obtaining highly informative markers of high polymorphism levels, because mutation rates are higher in dinucleotides than in 
tri- or tetranucleotides and are therefore widely used in genetic studies (Ellegren, 2004).

Locus amplification yielded 33 alleles (bands), with an average of 3.3 alleles per locus. Croxton et al. (2011) analyzed two SSR loci among D. bulbifera accessions with different origins (USA, Africa, and China) and found two and four alleles for each loci, respectively, with an average of 3.0 alleles, which is similar to our study. Siqueira et al. (2014) obtained an average of 5.1 alleles per locus among $89 \mathrm{D}$. alata accessions using 12 SSR loci. The average number of alleles per locus we found in D. bulbifera was also lower than the averages found by Hochu et al. (2006), Tostain et al. (2006), and Obidiegwu et al. (2009b), who found 7.6, 7.3, and 8.4 alleles per locus, respectively, in several species of Dioscorea. However, Sartie et al. (2012) found an average of 3.7 alleles per locus in $D$. alata, D. cayenensis, D. dumetorum, and D. rotundata.

The discrimination power values were calculated in order to compare the efficiency of the SSR markers for D. bulbifera. This parameter indicates a high level of polymorphism when its value is close to one. In our study, an average of 0.595 was found for this parameter, which may be considered a moderate to high value. Therefore, these primers had adequate discriminatory power, allowing them to detect high polymorphism among the genotypes. Siqueira et al. (2014) found an average of 0.92 for $D$. alata accessions, while Nascimento et al. (2013) found a lower average value (0.79) for $D$. trifida accessions, but still higher than the values found in this study.

Although a slight spatial structure was observed in both the principal coordinate and cluster analyses with the clustering of the Minas Gerais accessions, the other accessions were not classified into groups according to their origins, suggesting that high rates of gene flow have occurred between the accessions. Because the first two principal coordinates explained only $30.3 \%$ of the total variation and only one group was detected among the accessions in the Bayesian analysis, we conclude that the D. bulbifera accessions analyzed in this study have no spatial structure, although a slight spatial structure was detected in the principal coordinate analysis. An absence of genetic structure has been observed among D. alata accessions (Siqueira et al., 2014), suggesting that this result may be due to the behavior of farmers, who exchange tubers among their neighbors and friends resulting in a mixture of genotypes.

Only a few studies have been conducted on the genetic diversity of D. bulbifera. Ramser et al. (1996) assessed plants originating from Africa, Asia, and Polynesia, and found that the accessions were grouped according to their geographical origin. Terauchi et al. (1991) examined $D$. bulbifera using RFLP from cpDNA, and found a clear geographical distinction between accessions. Veasey et al. (2014) studied the genetic diversity of 17 D. bulbifera accessions from Vale do Ribeira using isozymes, and found high genetic diversity and nonspatial structuring among the accessions, agreeing with the results of our study.

Yam diversity may have been maintained by social and economic dynamics between local communities and traditional and ethnic groups that manage this diversity in different ways, depending on their history and the context in which they exist. Yam tubers can travel great distances from their places of origin thanks to migratory flows, because farmers can move to another state or municipality, or even use the tubers as gifts between friends and family, which is common in traditional societies (Siqueira, 2011).

Malapa et al. (2005) found no geographical differences between D. alata, D. nummularia, and D. transverse accessions (of Asian, African, and Melanesian origins, respectively) using AFLP markers, which confirmed the results of Lebot et al. (1998) who used isozyme markers for $D$. alata, and found that clones of these plants were widely distributed. For $D$. cayenensis/D. rotundata, Obidiegwu et al. (2009b) found no relationship between the 
accessions and their geographical areas of collection, possibly because the cultivars travelled large distances by human migration as clones. Yam cultivation is part of a dynamic, ongoing process, as observed by Scarcelli et al. (2013), as new genotypes of D. rotundata are regularly introduced and become widely used varieties. According to these authors, it may be possible to introduce new varieties that are better adapted to a novel biotic or abiotic environment (Scarcelli et al., 2013). However, D. bulbifera is not consumed in Brazil as much as D. rotundata is in Africa, and some questions remain to be answered, such as how traditional systems have created such genetic diversity, and for how long traditional agriculture will preserve these accessions in the field.

\section{Conflicts of interest}

The authors declare no conflict of interest.

\section{ACKNOWLEDGMENTS}

We thank Marcos Cella, Nivaldo Peroni, Lin C. Ming, José C. Feltran, Lidinalva R.G. da Silva, and Almecina B. Ferreira for field support, Dra. Anete Pereira Souza for laboratory facilities at UNICAMP, and agriculturists for providing the samples. Research supported by the Fundação de Apoio à Pesquisa do Estado de São Paulo (FAPESP, Proc. \#2007/04805-2) and Conselho Nacional de Desenvolvimento Científico e Tecnológico (CNPq).

\section{REFERENCES}

Billotte N, Lagoda PJL, Risterucci AM and Baurens FC (1999). Microsatellite-enriched libraries: applied methodology for the development of SSRs markers in tropical crops. Fruits 54: 277-288.

Bressan EA, Veasey EA, Peroni N, Felipim AP, et al. (2005). Collecting yam (Dioscorea spp.) and sweet potato (Ipomoea batatas) germplasm in traditional agriculture small-holdings in the Vale do Ribeira, São Paulo, Brazil. Plant Genet. Resour. Newsl. 144: 8-13.

Correa MP (1978). Dicionário de plantas úteis do Brasil e das exóticas cultivadas. Instituto Brasileiro de Desenvolvimento Florestal, Rio de Janeiro.

Creste S, Tulmann Neto A and Figueira A (2001). Detection of single sequence repeat polymorphisms in denaturing polyacrylamide sequencing gels by silver staining. Plant Mol. Biol. Rep. 19: 299-306. http://dx.doi.org/10.1007/ BF02772828

Croxton MD, Andreu MA, Williams DA, Overholt WA, et al. (2011). Geographic origins and genetic diversity of air-potato (Dioscorea bulbifera) in Florida. Invas. Plant Sci. Manage. 4: 22-30. http://dx.doi.org/10.1614/IPSM-D-10-00033.1

Dixit S, Mandal BB, Ahuja S and Srivastava PS (2003). Genetic stability assessment of plants regenerated from cryopreserved embryogenic tissues of Dioscorea bulbifera 1. Using RAPD, biochemical and morphological analysis. Cryo Lett. 24: 77-84.

Ellegren H (2004). Microsatellites: simple sequences with complex evolution. Nat. Rev. Genet. 5: 435-445. http://dx.doi. org $10.1038 / \operatorname{nrg} 1348$

Evanno G, Regnaut S and Goudet J (2005). Detecting the number of clusters of individuals using the software STRUCTURE: a simulation study. Mol. Ecol. 14: 2611-2620. http://dx.doi.org/10.1111/j.1365-294X.2005.02553.x

Hammer O, Harper DAT and Ryan PD (2001). PAST: Paleontological statistics software package for education and data analysis. Palaeontol. Electronica 4: 1-9.

Hochu I, Santoni S and Bousalem M (2006). Isolation, characterization and cross-species amplification of microsatellite DNA loci in the tropical American yam Dioscorea trifida. Mol. Ecol. Notes 6: 137-140. http://dx.doi.org/10.1111/ j.1471-8286.2005.01166.x

Lebot V (2009). Tropical root and tuber crops: cassava, sweet potato, yams and aroids. In: Pests and diseases. (Lebot V, eds.). CAB International, Wallingford, 253-264. 
Lebot V, Trilles B, Noyer JL and Modesto J (1998). Genetic relationships between Dioscorea alata L. cultivars. Genet. Resour. Crop Evol. 45: 499-509. http://dx.doi.org/10.1023/A:1008603303314

Malapa R, Arnau G, Noyer JL and Lebot V (2005). Genetic diversity of the greater yam (Dioscorea alata L.) and relatedness to D. nummularia Lam. and D. transversa Br. as revealed with AFLP markers. Genet. Resour. Crop Evol. 52: 919-929. http://dx.doi.org/10.1007/s10722-003-6122-5

Martin FW and Ortiz S (1963). Chromosome number behaviour in some species of Dioscorea. Cytologia (Tokyo) 28: 96101. http://dx.doi.org/10.1508/cytologia.28.96

Mengesha WA, Demissew S, Fay MF, Smith RJ, et al. (2013). Genetic diversity and population structure of Guinea yams and their wild relatives in South and South West Ethiopia as revealed by microsatellite markers. Genet. Resour. Crop Evol. 60: 529-541. http://dx.doi.org/10.1007/s10722-012-9856-0

Narula A, Kumar S, Bansal KC and Srivastava PS (2003). In vitro micropropagation, differentiation of aerial bulbils and tubers and diosgenin content in Dioscorea bulbifera. Planta Med. 69: 778-779.http://dx.doi.org/10.1055/s-2003-42781

Nascimento WF, Rodrigues JF, Koehler S, Gepts P, et al. (2013). Spatially structured genetic diversity of the endangered Amerindian yam (Dioscorea trifida L.) assessed by SSR and ISSR markers in Southern Brazil. Genet. Resour. Crop Evol. 60: 2405-2420. http://dx.doi.org/10.1007/s10722-013-0008-y

Obidiegwu JE, Rodriguez E, Ene-obong EE, Loureiro J, et al. (2009a). Estimation of the nuclear DNA content in some representative of genus Dioscorea. Sci. Res. Essays 4: 448-452.

Obidiegwu JE, Kolesnikova-Allen M, Ene-Obong EE, Muoneke CO, et al. (2009b). SSR markers reveal diversity in Guinea yam (Dioscorea cayenensis/D. rotundata) core set. Afr. J. Biotechnol. 8: 2730-2739.

Pritchard JK, Stephens M and Donnelly P (2000). Inference of population structure using multilocus genotype data. Genetics 155: 945-959.

Ramser J, Weising K, Kahl G, López-Peralta C, et al. (1996). Genomic variation and relationships in aerial yam (Dioscorea bulbifera $\mathrm{L}$.) detected by random amplified polymorphic DNA. Genome 39: 17-25. http://dx.doi.org/10.1139/g96-003

Sartie A, Franco J and Asiedu R (2012). Phenotypic analysis of tuber yield- and maturity-related traits in white yam (Dioscorea rotundata). Afr. J. Biotechnol. 11: 3964-3975.

Scarcelli N, Daïnou O, Agbangla C, Tostain S, et al. (2005). Segregation patterns of isozyme loci and microsatellite markers show the diploidy of African yam Dioscorea rotundata $(2 \mathrm{n}=40)$. Theor. Appl. Genet. 111: 226-232. http:// dx.doi.org/10.1007/s00122-005-2003-y

Scarcelli N, Barnaud A, Eiserhardt W, Treier UA, et al. (2011). A set of 100 chloroplast DNA primer pairs to study population genetics and phylogeny in monocotyledons. PLoS One 6: e19954. http://dx.doi.org/10.1371/journal. pone.0019954

Scarcelli N, Couderc M, Baco MN, Egah J, et al. (2013). Clonal diversity and estimation of relative clone age: application to agrobiodiversity of yam (Dioscorea rotundata). BMC Plant Biol. 13: 178. http://dx.doi.org/10.1186/1471-2229$\underline{13-178}$

Silva LRG, Bajay MM, Monteiro M, Mezette TF, et al. (2014). Isolation and characterization of microsatellites for the yam Dioscorea cayenensis (Dioscoreaceae) and cross-amplification in D. rotundata. Genet. Mol. Res. 13: 2766-2771. http://dx.doi.org/10.4238/2014.April.14.5

Siqueira MVBM (2011). Yam: a neglected and underutilized crop in Brazil. Hortic. Bras. 29: 16-20.

Siqueira MVBM, Marconi TG, Bonatelli ML, Zucchi MI, et al. (2011). New microsatellite loci for water yam (Dioscorea alata, Dioscoreaceae) and cross-amplification for other Dioscorea species. Am. J. Bot. 98: e144-e146.http://dx.doi. org/10.3732/ajb.1000513

Siqueira MVBM, Bonatelli ML, Günther T, Gawenda I, et al. (2014). Water yam (Dioscorea alata L.) diversity pattern in Brazil: an analysis with SSR and morphological markers. Genet. Resour. Crop Evol. 61: 611-624. http://dx.doi. org/10.1007/s10722-013-0063-4

Sosinski B, Gannavarapu M, Hager LD, Beck E, et al. (2000). Characterization of microsatellite markers in peach. Theor. Appl. Genet. 101: 421-428. http://dx.doi.org/10.1007/s001220051499

Sougata G, Mehul A and Sumersing P (2012). Antidiabetic activity of Gnidia glauca and Dioscorea bulbifera: potent amylase and glucosidase inhibitors. Evidence-Based Compl. Altern. Med. Doi: 10.1155/2012/929051.

Tamiru M, Becker HC and Maass BL (2007). Genetic diversity in yam germplasm from Ethiopia and their relatedness to the main cultivated Dioscorea species assessed by AFLP markers. Crop Sci. 47: 1744-1753. http://dx.doi. org/10.2135/cropsci2006.11.0719

Temnykh S, DeClerck G, Lukashova A, Lipovich L, et al. (2001). Computational and experimental analysis of microsatellites in rice (Oryza sativa L.): frequency, length variation, transposon associations, and genetic marker potential. Genome Res. 11: 1441-1452. http://dx.doi.org/10.1101/gr.184001

Terauchi R, Terachi T and Tsunewaki K (1991). Intraspecific variation of chloroplast DNA in Dioscorea bulbifera L. Theor. Appl. Genet. 81: 461-470. http://dx.doi.org/10.1007/BF00219435

Genetics and Molecular Research 15 (2): gmr.15027929

CFUNPEC-RP www.funpecrp.com.br 
Tessier C, David J, This P, Boursiquot JM, et al. (1999). Optimization of the choice of molecular markers for varietal identification in Vitis vinifera L. Theor. Appl. Genet. 98: 171-177. http://dx.doi.org/10.1007/s001220051054

Tostain S, Scarcelli N, Brottier P, Marchand JL, et al. (2006). Development of DNA microsatellite markers in tropical yam (Dioscorea sp.). Mol. Ecol. Notes 6: 173-175. http://dx.doi.org/10.1111/j.1471-8286.2005.01182.x

Tostain S, Agbangla C, Scarcelli N, Mariac C, et al. (2007). Genetic diversity analysis of yam cultivars (Dioscorea rotundata Poir) in Benin using simple sequence repeat (SSR) markers. Plant Genet. Resour. 5: 71-81. http://dx.doi. org/10.1017/S1479262107672323

Veasey EA, Siqueira MVBM, Gomes LR, Nascimento WF, et al. (2010). Ocorrência e diversidade de espécies cultivadas do gênero Dioscorea em diversos agroecossistemas brasileiros. In: Agrobiodiversidade no Brasil: experiências e caminhos da pesquisa (Kffuri CW, Amorozo MC and Ming LC, eds.). NUPEEA, Recife, 45-74.

Veasey EA, Bressan EA, Siqueira MVBM, Borges A, et al. (2014). Genetic diversity and population structure in five cultivated Dioscorea spp. (Dioscoreaceae) using molecular markers. In: Bulbous plants biotechnology (Ramawat KG and Mérillon JM, eds.). CRC Press, Taylor \& Francis Group, Boca Raton, 50-74.

Yan QQ, Li Y, Sun XQ, Guo JL, et al. (2014). Isolation and characterization of polymorphic microsatellite loci from aerial yam (Dioscorea bulbifera L.). Genet. Mol. Res. 13: 1514-1517. http://dx.doi.org/10.4238/2014.March.12.3 